\title{
The Role Of Duty Complexity As A Moderation Of The Influence Auditor's Professional Knowledge And Ethics On Audit Quality (Empirical Study On Auditor At KAP Central Java)
}

\author{
Widhy Setyowati ${ }^{1}$, Pratomo Cahyo Kurniawan ${ }^{2}$, Aditya Mardiansyah ${ }^{3}$, Eka Purnama \\ Harahap ${ }^{4}$, Ninda Lutfiani ${ }^{5}$ \\ 1,2 STIE Bank BPD Jateng \\ 3,4,5Raharja University, Tangerang \\ E-mail : widhisetyowati61@gmail.com ${ }^{1}$, \\ pratomocahyokurniawan@stiebankbpdjateng.ac.id ${ }^{2}$, aditya.mardiansyah@raharia.info ${ }^{3}$, \\ ekapurnamaharahap@raharja.info ${ }^{4}$, ninda@raharja.info ${ }^{5}$
}

\section{To cite this document :}

Setyowati, W., Kurniawan, P., Mardiansyah, A., Harahap, E., \& Lutfiani, N. (2021). The Role Of Duty Complexity As A Moderation Of The Influence Auditor's Professional Knowledge And Ethics On Audit Quality. Aptisi Transactions on Management (ATM), 5(1), 20-29.

DOI :

https://doi.org/10.33050/atm.v5i1.1483

\section{Abstract}

This study aims to analyze the effect of professional knowledge and auditor ethics to audit quality with task complexity as moderating variable. which consists of 80 respondents, data collection methods using questionnaires, data analysis methods using multiple linear regression analysis and data processing using SPSS application. From the results of the partial test, professional knowledge variable gives positive and significant effect to the quality of audit quality, as well as the auditor ethics variable that gives positive and significant effect to audit quality. Task complexity can not moderate the effect of professional knowledge to audit quality but task complexity as moderate variable the effect of auditor ethics to audit quality. Those variables simultaneously have the positive and significant influence to the audit quality.

Keyword: Professional Knowledge, Auditor Ethics, Audit Quality, Task Complexity

\section{Introduction}

Audit Standards (SA) 200 paragraph 3 states that the objective of an independent audit is to provide assurance to users of financial statements that the client's financial statements are free from fraud and material misstatement [1]. The audit report is an important output of the audit process [2]. The quality of audit reports is difficult to measure because the auditor's opinion is very sensitive to the behavior of individuals who carry out audit work. Auditing standards state that in order to produce quality audit reports to make decisions, auditors must actually carry out several stages of audit procedures in accordance with those stipulated in the Public Accountants Professional Standards.

Several cases that occurred in Indonesia indicated the low quality of audits produced by auditors [3], such as the case that occurred in 2012, the Ministry of Finance of the Republic of Indonesia revoked the business activities of four APs practicing in the capital market sector and fined 65 APs totaling Rp 179,900,000, - and one AP is subject to written warning sanctions. suspended the permits of AP Ben Ardi, CPA and KAP Achmad, Rasyid, Hisbullah and Jerry branch offices in Jakarta (http://pppk.kemenkeu.go.id/News). Furthermore, data obtained from the Financial Professional Development Center (P2PK) of the Ministry of Finance of the Republic 
of Indonesia, in 2015 found 1 case of violation which resulted in freezing of public accountant's license. In 2016 there were no violations found, but in 2017 there were 9 violations of the audit standard (SA) and the public accountant professional standard (SPAP) which resulted in freezing and even revoking the license of a public accountant [4]. Most of the violations were related to the unavailability of audit report working papers [5]. This shows that violations are related to low audit quality.

Violations of auditing standards, professional standards and accounting codes of ethics involve companies (clients) and public accounting firms (KAP) which lead to a decline in audit quality [6]. The low quality of audits is caused by low professional knowledge such as low understanding and adherence to Auditing Standards (SA), Financial Accounting Standards (SAK) and Public Accountants Professional Standards (SPAP) have been carried out [7] [8] [9].

Audit violations related to auditor ethics are indicated by the auditor's non-compliance with the applicable professional code of ethics established by KAP [7]. Actions taken by auditors in implementing audit programs that directly reduce audit quality are called audit quality reduction behaviors [10], while actions that can reduce audit quality are indirectly referred to as under reporting of time [11]. These behaviors constitute a serious threat to audit quality because the evidence and audit procedures gathered during the audit are not sufficient as a basis for the auditor to express an opinion regarding the fairness of the financial statements being audited [12].

Task complexity is the individual's perception of the difficulty of a task caused by limited capabilities and memory and the ability to integrate the problems they have. The results of research in Indonesia, prove that the complexity of the audit task has a negative effect on audit decisions [13] [14], this proves that the higher the complexity of the tasks faced by auditors will have a negative impact on the quality of the resulting audit [15].

Based on several previous studies, it has shown that task complexity can moderate performance, repetitive assignments and job creativity. One of the auditors' performance in KAP is indicated by the quality of the audit reports produced. For this reason, the complexity of the task in this study is proposed as a moderating variable for the effect of professional knowledge and auditor ethics on audit quality [16].

The aim of this study was to identify the variables of professional knowledge and auditor ethics to be tested for their effect on audit quality with task complexity as moderation.

\section{Relationship Between Variables and Hypothesis Development \\ 2.1. Effect of Professional Knowledge on Audit Quality}

Professional knowledge is a strategic resource possessed by auditors to carry out audit assignments, this is in accordance with the Resource Based View theory. Thus auditors who have extensive knowledge will be able to produce better audit quality. Important auditors have technical knowledge, technical knowledge that has been designed and managed must be supported by professionalism, leadership and high personal qualities [17]. This is intended to achieve success in carrying out tasks, for auditors are reflected in high audit quality [18]. In addition to technical knowledge, auditors also need to increase practical knowledge gained from experience, thus in order to improve audit quality, auditors need to increase their technical and practical knowledge, both of which are called professional knowledge.

Explain that practical knowledge can change practical behavior to become professional, where practical knowledge can produce audit quality such as speed and credibility of financial reports [18]. The experience of auditors plays a role in making auditor judgments which in turn can improve the quality of the audit.

Stated that several provisions in The Companies Act 1965 require auditors to have competence, expertise and independence before being appointed as auditors. This encourages auditors to have technical and practical qualifications from clients before conducting audits [19]. Qualifications / technical knowledge and qualifications / practical knowledge are considered important in predicting auditor performance, in the form of audit quality. It can be interpreted that auditors as independent professional workers must have professional knowledge to improve the quality of their audits. From the description above, hypothesis 1 is compiled

$H_{1}$ : Professional knowledge has a positive effect on audit quality.

\subsection{Effect of Auditor Ethics on Audit Quality}


Auditor ethics is one of the strategic resources that auditors have in carrying out their profession to produce high audit quality. Define auditor ethics as individual morale, virtue, thoughts, and good thinking, especially in independent jobs such as doctors, auditors. and others [18]. In relation to the profession of auditors, individual morals are exemplified such as integrity, objectivity and independence. Virtue values (noble ideals) such as truth, honesty, transparency and accountability [20]. Mind is explained as an understanding of the values of virtue [21]. Good thinking is exemplified as prioritizing audit quality.

Ethics is a value held by a person or group in regulating their behavior. That is, the consideration of doing a particular job systematically [22] recommends how to do the job effectively and how to behave ethically. On the other hand, explains that ethics is a basic component for perceptions of integrity, objectivity and auditor independence in providing audit opinions [23]. Thus the use of auditor ethics in audit assignments teaches professional auditors to complete audit work with honesty, morality and high quality [24].

Indonesian Accountants Code of Ethics Article 1 paragraph 2 mandates that each member must maintain integrity and objectivity in carrying out their duties. This explanation can be interpreted that the auditor in analyzing audit evidence and preparing audit reports must always maintain integrity, objectivity and independence. From the description above, hypothesis 2 is compiled.

\section{$H_{2}$ : Auditor ethics have a positive effect on audit quality.}

\subsection{Task complexity moderates the influence of professional knowledge and ethics of auditors on audit quality.}

Task complexity is an individual's perception of the difficulty of a task caused by limited capabilities and memory and the ability to integrate the problems they have. Furthermore, the complexity of the task is related to the level of innovation, the audit judgment required by the auditor in completing the audit assignment.

There are three basic reasons why it is necessary to conduct a task complexity test for an audit situation. First, the complexity of this task is thought to have a significant effect on auditor performance. Second, certain decision-making tools and techniques and exercises are thought to have been conditioned in such a way that researchers understand the peculiarities of the complexity of the audit task. Third, understanding the complexity of the audit and the audit task.

Research conducted proves that task complexity has a negative effect on audit decisions [15]. The higher the level of complexity of the tasks an auditor is carrying, the lower the audit quality. Research conducted proves that audit complexity has a significant effect on audit quality [25] [26].

The role of task complexity as a moderating variable has been carried out by several researchers. Tested the role of task complexity moderation on the effect of incentives on repeated assignments with the results of the study that task complexity moderated the effect of incentives on repeated assignments. Examined the role of task complexity as a moderating variable for the effect of incentives on audit judgment [27]. Examined the role of task complexity on the effect of experience and performance [28]. Task complexity moderates the effect of professional knowledge and auditor ethics on audit quality. The hypothesis proposed is as follows:

$\mathrm{H}_{3}$ : Task complexity moderates the effect of professional knowledge on audit quality. $\mathrm{H}_{4}$ : Task complexity moderates the effect of auditor ethics on audit quality.

\section{Research Methods}

The study population was auditors who worked at the Public Accounting Firm (KAP) in Central Java. The sampling technique was carried out by using a non-probability sampling technique, namely purposive sampling with the following criteria: (a) Auditors who work in public accounting offices have at least a bachelor's degree (S1). (b) The auditor has worked for a minimum of two years and is involved in conducting the audit.

The Role Of Duty Complexity As A Moderation Of The Influence Of Auditor's Professional Knowledge And Ethics On Audit Quality (Empirical Study On Auditor At Kap Central Java)

(Widhy Setyowati) 
The data of this research is a cross section, which is the collection of data at a certain time / period obtained from auditors who work at KAP in Central Java. This study uses a survey method. In this study, the type of data used is primary data. The research instrument used was a questionnaire, namely by distributing questionnaires to respondents which contained a series of written statements regarding the variables to be studied, including professional knowledge, auditor ethics, task complexity and audit quality. A number of statements were submitted to respondents and then the respondents were asked to answer according to their opinions. To measure the respondent's opinion, a five-digit scale was used, starting with number 5 for strongly agreeing opinion (SS) and number 1 for strongly disagreeing (STS).

In this study, the data used will be processed using SPSS analysis tools with multiple regression tests. After the data is collected, then the data will be processed using descriptive statistical tests to see the mean [29], test data quality using Confirmatory Factor Analysis (CFA) to see validity and reliability, and to see normality, multicollinearity and heteroscedasticity using the classical assumption test.

Meanwhile, the data analysis technique is linear regression with the model test both the $\mathrm{F}$ test which explains the simultaneous effect of the coefficient of determination (Adjusted R2) and hypothesis testing (t-test) to see the effect of each independent variable on the dependent variable.

\section{Research Results and Discussion}

\subsection{Respondent Description}

Data collection was carried out by sending questionnaires directly to $21 \mathrm{KAP}$ in Central Java and collected as many as 80 questionnaires, then the data were tabulated and processed and analyzed further [30]. From the results of the research data collection, most of the respondents were male $(70 \%)$ with the greatest age between 30-35 years. Most of the auditors have a bachelor's degree (S1) and a few have a master's degree and PPAk. From these data, it shows that accountants who are expected to work professionally, both those obtained through formal education for Strata1 (S1) and Masters (S2) and have attended professional education (PPAk) have been fulfilled.

\subsection{Data Quality Test}

\section{Validity test}

Based on the results of the validity test of the Audit Quality variable, the KMO value was 0.746 , greater than 0.5 (>0.5), meaning that the sample size met the minimum requirements. The indicator that has a loading value less than 0.4 is Y.3. So that the other 13 indicators are declared valid. The results of the validity test on the Professional Knowledge variable obtained a KMO value of 0.766 ( $>0.5$ ), meaning that the number of samples met the minimum requirements. The indicator that has a loading value less than 0.4 is $\mathrm{X} 1.1$. So that the 12 other indicators are declared valid. The results of the validity test of the Auditor Ethics variable as measured by 11 statement indicators obtained a KMO value of $0.746(>0.5)$, meaning that the number of samples met the minimum requirements and all indicators showed a loading factor> 0.4 , meaning that all indicators were declared valid. The test results for the validity of the Task Complexity variable as measured by 5 statement indicators obtained a KMO value of 0.809 (> $0.5)$, meaning the number of samples met the minimum requirements and 4 indicators showed a loading factor $>0.4$ and 1 indicator showed a loading factor $<0.4$ (Z.5). Means 4 valid indicators and 1 invalid indicator.

\section{Reliability Test}

Reliability test is used to test the reliability of a measuring device to be used again for the same research. Reliability testing in this study is using the Cronbach Alpha formula. The results of testing the reliability of the Audit Quality variable are 0.890 , Professional Knowledge 0.862 , Auditor Ethics 0.825 and Task Complexity 0.860 . From these results indicate that all variables have an Alpha coefficient that is large enough, which is above 0.70 , so it can be said that all the 
concepts of measuring the variables used in this study are reliable. Henceforth, the items in each of these variable concepts are suitable for use as a measuring tool in statistical testing.

\subsection{Classic assumption test.}

Normality Test using Histogram Graph. Normality test results shows a residual (confounding error) that is normally distributed because the histogram graph test results show an image with a certain pattern.

Multicollinearity testing is carried out using the VIF value. Multicollinearity testing is carried out on the regression model. The multicollinearity test results show that all independent variables have a VIF value that is far below the number 10 , so it can be said that all the concepts measuring the variables used do not contain multicollinearity problems.

Heteroscedasticity testing was done using the Scatter Plot test. The results of the heteroscedasticity test showed that there was no pattern that indicated a significant relationship between the predictors and their residual values. This means that the regression model has no symptoms of heteroscedasticity.

\subsection{Model test}

The statistical calculation in multiple linear regression analysis used in this study is to use the help of the SPSS computer program. The results of data processing using the SPSS program to test the effect of professional knowledge and Eika auditors on audit quality are shown in the following table:

Table 1

The results of multiple linear regression analysis

\begin{tabular}{|c|c|c|c|}
\hline \multirow{2}{*}{ Model } & $\begin{array}{c}\text { Standardized } \\
\text { Coefficients }\end{array}$ & \multirow{2}{*}{$T$} & S Sig. \\
\cline { 2 - 2 } & Beta & \\
\hline
\end{tabular}

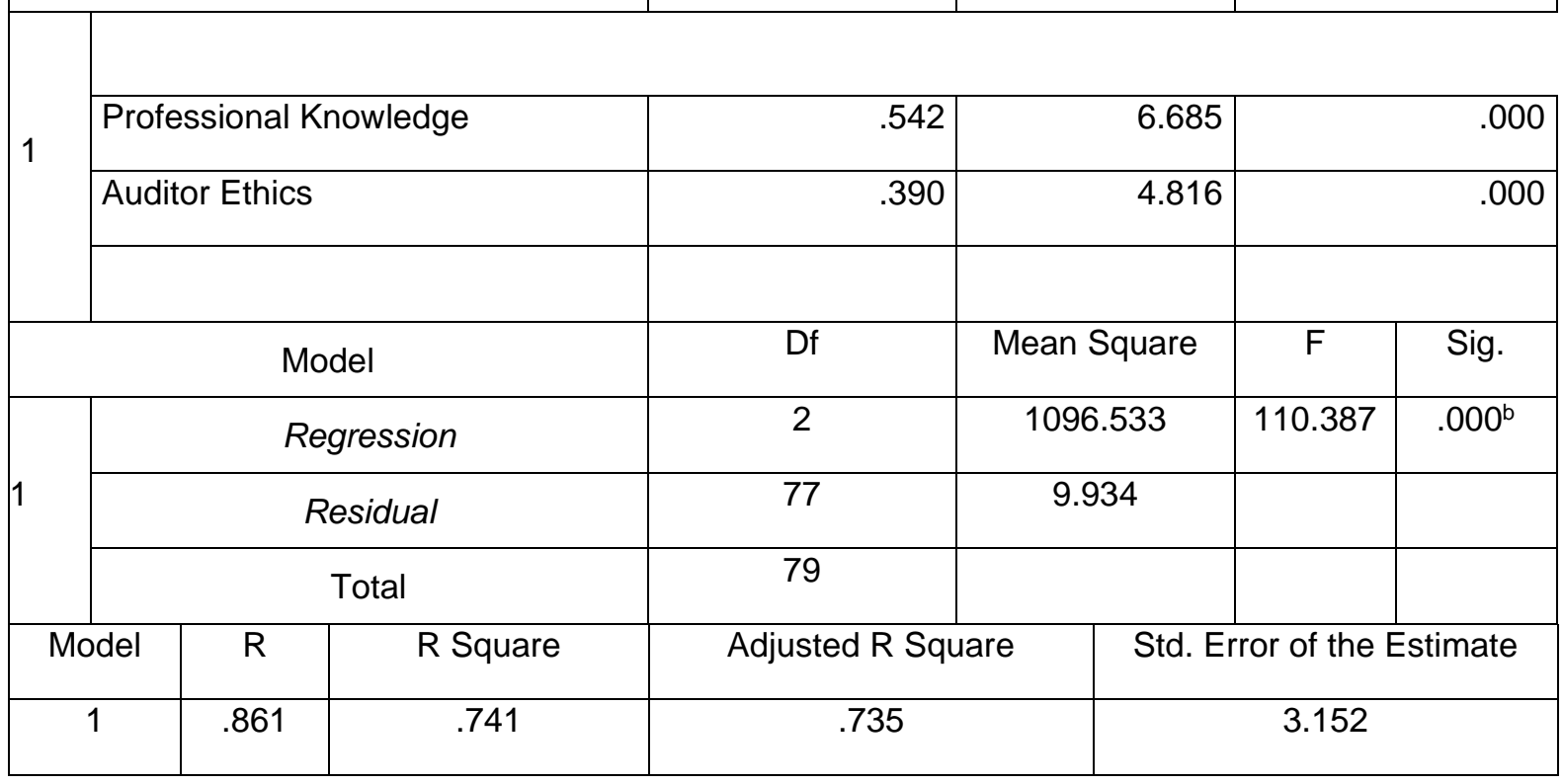

The results of empirical testing show the calculated $F$ value of 110,387 with a significance of 0,000 , thus it can be said that the professional knowledge and ethics of the auditors together have an effect on audit quality.

The coefficient of determination (adjusted $R^{2}$ ) to measure how much the independent variable's ability to explain the dependent variable. The calculation result obtained is 0.735 . This shows that $73.5 \%$ audit quality is influenced by the variables of Professional Knowledge and Auditor Ethics and the remaining $26.5 \%$ is influenced by other variables.

\subsection{Discussion}

The Role Of Duty Complexity As A Moderation Of The Influence Of Auditor's Professional Knowledge And Ethics On Audit Quality (Empirical Study On Auditor At Kap Central Java)

(Widhy Setyowati) 


\section{Hypothesis Discussion 1}

Hypothesis 1 test results show the beta coefficient of .542 with a significance of .000 , this means that professional knowledge has a positive effect on audit quality. Acceptance of hypothesis 1 provides empirical evidence that the better an auditor's professional knowledge will improve his audit quality. The professional knowledge of an auditor in this study is seen from the technical knowledge obtained from college, practical knowledge obtained from the length of time he worked as an auditor and practical knowledge from the many audit assignments.

The results of statistical descriptions show that the average respondent's answer (auditor) answers is 4.19 (agree), these results indicate that on average the auditors who are respondents are: have an understanding of audit techniques, have an understanding of indications of error or fraud, have knowledge of accounting and auditing, have an understanding of evidence collection procedures, the adequacy and competence of audit evidence and have knowledge of how to deal with clients in obtaining the required data and information.

This statement is reinforced by the results of the statistical description X1.10 showing the cumulative number of answers to 3 (Neutral) of $22.5 \%$ for the statement that the longer you become an auditor, the easier it is to find the causes of errors and fraud and can provide recommendations to eliminate or minimize these causes. This indicates that the auditors who become respondents have the practical ability to find the causes of errors and fraud so that they do not need to be related to the length of their duties as auditors. Likewise, the results of statistical descriptions for X1.13 show the amount of answer 3 (Neutral) of 18 respondents or $22.5 \%$ for statements about the number of mistakes and the selection of audit evidence that have been made, increasing the auditor's knowledge about how to detect errors, fraud and material misstatements. that the client does. This indicates that the auditors as respondents have practical knowledge to detect errors and fraud and are not always related to the many mistakes in collecting and selecting audit evidence.

Audit quality in this study is seen from the dimensions of operational input, audit process and audit output. The average auditor who is the respondent of this study answered 4.17 , this shows that on average the auditors who are respondents in issuing audit reports and auditor opinions are based on the results of audits carried out in accordance with auditing standards and the provisions of applicable laws, the formulation of opinions is based on the results of the evaluation regarding the conclusions drawn from the audit evidence obtained and documented adequately in the auditor's working paper, and the audit report is presented objectively in accordance with the SPAP and submitted on time according to the engagement.

This statement is also strengthened by the results of statistical descriptions for the Y4 indicator showing the answers of respondents who are in doubt so that the accumulated answers of 3 (neutral) are $45 \%$ related to the statement. carried out by permanent staff (fulltime) can reduce the quality of the audit. This indicates that the auditor's opinion as a respondent states that auditors who work in the field are not affected by their status as permanent or freelance workers, but they still work in accordance with auditing standards and applicable regulations.

The research findings that show that the higher the professional knowledge the auditor has, the higher the resulting audit quality is supported that there is a positive and significant influence between professional knowledge and audit quality [31]. This is consistent with the findings of [18] that Professional knowledge tends to be the main determinant of the quality of the auditor's job. Likewise, proves that professional knowledge can improve audit quality and proves that professionalism has a significant positive effect on auditor performance.

\section{Hypothesis Discussion 2}

Hypothesis 2 testing shows a beta coefficient of .390 with a significance of 0.000 , this provides empirical evidence that Auditor Ethics affects audit quality in a positive direction. Acceptance of hypothesis 2 provides empirical evidence that better auditor ethics will improve audit quality. This study looks at the ethics of auditors from the dimensions of integrity, objectivity and independence.

The results of the statistical description of the auditor ethics variable (X2) show an average of 4.16 or agree with the statement submitted to the respondent (auditor). These results provide empirical evidence that on average the auditors who are respondents dare to disclose things that according to their considerations and beliefs need to be done when performing audit tasks, perform audit tasks in accordance with facts and do not find fault or hide mistakes, and maintain 
honesty and obey the rules in performing audit tasks. Valid auditor ethics indicators come from integrity, objectivity and independence.

These findings are reinforced by the results of statistical descriptions where the highest average of the three dimensions is shown in X2.8 that the auditor agrees in deciding materiality and that the audit risk assessment is not adjusted to client requests. This provides empirical evidence that auditors in carrying out their audit duties have upheld their independence.

Auditor ethics is a strategic value for auditors to produce audit quality. Auditor's strategic resources in the form of integrity, objectivity and independence determine the quality of the auditor's work. With high auditor ethics, auditors are able to produce high audit quality so that they have a competitive advantage and can continue to survive.

The results of this study are consistent with the findings of [18] that auditor ethics can improve audit quality. Likewise, the findings of [32] that integrity and objectivity have a positive effect on the ability of auditors to detect fraud. On the other hand, proved that professional ethics has a significant positive effect on auditor performance.

\section{Discussion of Hypotheses 3}

Hypothesis 3 is proposed, testing the variable complexity of the task as a moderation of professional knowledge on audit quality. The results of this study indicate the results of the t-test effect of professional knowledge on audit quality with a beta coefficient of 0.902 with a significance of .008 , this provides empirical evidence that professional knowledge has a positive effect on audit quality. However, the complexity of the task shows the statistical results of the beta coefficient .761 with a significance level of $.107(>0.05)$, which means that task complexity has no significant effect on audit quality. Likewise, the results of the X1.Z moderation statistic show a beta coefficient of -.678 with a significance of .347 or greater than 0.05 , this proves that task complexity does not moderate the effect of professional knowledge on audit quality.

These findings provide empirical evidence that auditors as respondents in carrying out their audit duties have professional knowledge in the form of accounting and auditing knowledge [33], understanding of indications of fraud, and understanding of audit procedures that can improve audit quality. On the other hand, the auditor as a respondent has the perception that complex or ambiguous tasks can be overcome with their knowledge and experience, therefore task complexity has no effect on audit quality. Likewise, the results of the moderation test provide empirical evidence that task complexity does not strengthen or weaken the effect of professional knowledge on audit quality.

\section{Discussion of the hypothesis 4}

Hypothesis 4 is proposed, testing task complexity as a moderating variable for the effect of professional ethics on audit quality. The results of statistical testing prove that the interaction between auditor ethics and task complexity (X2.Z against $Y$ ) shows a beta coefficient of 1.335 with a significance level of .010 . Thus hypothesis 4 is proven, these results provide empirical evidence that task complexity moderates the effect of auditor ethics on task quality in a positive direction which means strengthening.

The results of this study are supported by the results of statistical descriptions that show the answers of the auditors as respondents with a high average score for indicators 1 to 4 . This indicates that the auditor states that the assigned tasks have been well formulated, the audit approach can help complete the task, by general auditors are of the opinion that they easily determine the appropriateness of procedures for the completion of their duties and auditors are of the opinion that they have judgments to determine when sufficient evidence has been gathered. Previous research conducted noted that the level of complexity of the audit task can impose a heavy mental workload on individual decision makers, which in turn can reduce the quality of decisions. However, the results of this study prove that auditors can overcome the diversity of tasks faced by promoting integrity and objectivity.

This indicates that the auditor as a respondent has integrity, objectivity and maintains his independence if he is given structured tasks or the procedures are well planned or in other words, it is not ambiguous and will be able to produce high quality audits.

\section{Conclusion}

The Role Of Duty Complexity As A Moderation Of The Influence Of Auditor's Professional Knowledge And Ethics On Audit Quality (Empirical Study On Auditor At Kap Central Java)

(Widhy Setyowati) 


\subsection{Managrial Advice}

Based on the results of data analysis and hypothesis testing, the research resulted in several findings which are summarized as follows:

1. The professional knowledge possessed by auditors improves audit quality. The higher the professional knowledge the auditor has, the better the audit quality will be. Ownership of professional knowledge by the auditor enables the auditor to provide a high level of assurance to users of financial statements.

2. Auditor's ethics can improve audit quality. The more ethical the auditor, the better the resulting audit quality. Auditors apply their ethics in the form of integrity and objectivity and uphold independence.

3. The complexity of the task does not moderate the effect of professional knowledge on audit quality. Auditors who have professional understanding / knowledge in the form of technical knowledge acquired in college and practical knowledge gained during their duties as auditors can overcome complex audit tasks in an effort to produce quality audits so that it can be said that task complexity does not strengthen or weaken influence. professional knowledge of audit quality.

4. Task complexity moderates the effect of auditor ethics on audit quality. Auditors who are ethical or auditors who have integrity, objectivity and uphold independence when faced with structured and unambiguous tasks, will be able to improve audit quality.

\subsection{Policy Implications}

1. The results show that the professional knowledge and ethics of auditors have a positive effect on audit quality. Therefore, the policy implication of this research result for public accounting professional organizations is to pay attention to audit standards related to professional knowledge and ethics possessed by auditors to carry out audit tasks in order to improve Public Accountant Professional Standards, Professional Standards and Quality Control Standards in order to produce high audit quality.

2. The results show that task complexity moderates the effect of auditor ethics on audit quality. Policy implications for public accounting professional organizations need to determine procedures and work procedures for auditors on each audit assignment so as not to cause confusion or job ambiguity.

\subsection{Limitation}

1. Most of the respondents are junior auditors who have less than 5 years of experience and are relatively young, even though the objectives of this study are all levels of auditors. Therefore, the research results have not been able to generalize the role of improving audit quality.

2. The research does not cover all the characteristics of auditors that may affect the improvement of audit quality.

\subsection{Future Research Suggestions}

1. It is necessary to use a survey method that is more persuasive to senior auditors and partner auditors, so that they can get more information about the audit quality input, process and output.

2. Examine other variables that are likely to influence the improvement of audit quality such as organizational culture or leadership.

\section{Reference}

[1] S. P. A. Publik, "Institut Akuntan Publik Indonesia," Jakarta: Salemba Empat, 2011.

[2] W. Setyowati, "Overview: Perkembangan Standar Audit yang Relevan dengan Keputusan Opini Going Concern," Kaji. Akunt., vol. 1, no. 1, pp. 58-68, 2009.

[3] D. B. Pangesti and W. Setyowati, "PENGARUH PERSEPSI ETIS, PENGALAMAN AUDITOR, TEKANAN KETAATAN DAN KOMPLEKSITAS TUGAS TERHADAP KUALITAS AUDIT JUDGEMENT," 2018.

[4] Q. Aini, U. Rahardja, E. S. Aisyah, and A. Khoirunisa, "Performa Kinerja Admin Layanan Keuangan Mahasiswa Menggunakan Dashboard Pada Web Based Accounting Online," Inform. Mulawarman J. IIm. IImu Komput., vol. 15, no. 1, pp. 21-26, 2020.

[5] F. A. Nugroho and W. Setyowati, "PENGARUH KOMITMEN ORGANISASIONAL, SISTEM INFORMASI AKUNTANSI, DAN PERAN AUDIT INTERNAL TERHADAP 
KUALITAS LAPORAN KEUANGAN," ECONBANK J. Econ. Bank., vol. 1, no. 2, pp. 125134, 2019.

[6] Q. Aini, U. Rahardja, A. H. Arribathi, and N. P. L. Santoso, "Penerapan Cloud Accounting dalam Menunjang Efektivitas Laporan Neraca pada Perguruan Tinggi," Comput. Eng. Sci. Syst. J., vol. 4, no. 1, pp. 60-64, 2019.

[7] A. Amrizal, "Analisis Kritis Pelanggaran Kode Etik Profesi Akuntan Publik Di Indonesia," Liquidity, vol. 3, no. 1, pp. 36-43, 2014.

[8] U. Rahardja, Q. Aini, and M. Hardini, "Penerapan Software Akuntansi Online Sebagai Penunjang Pencatatan Laporan Keuangan," SISFOTENIKA, vol. 8, no. 2, pp. 176-187, 2018.

[9] U. Rahardja, Q. Aini, N. Azizah, and N. P. L. Santoso, "Efektivitas Akuntansi Online dalam Menunjang Proses Rekonsiliasi," NJCA (Nusantara J. Comput. Its Appl., vol. 3, no. 2, pp. 105-112, 2018.

[10] L. Nirmalasari, E. P. Harahap, and F. Faradilla, "Implementation of Problem Formulation Management in Improving the Quality of Research in Higher Education," Aptisi Trans. Manag., vol. 2, no. 1, pp. 20-27, 2018.

[11] B. Basuki and K. Y. Mahardani, "Pengaruh tekanan anggaran waktu terhadap perilaku disfungsional auditor dan kualitas audit pada kantor akuntan publik di Surabaya," $J$. Manajemen, Akunt. Sist. Inf., vol. 6, no. 2, pp. 203-223, 2006.

[12] W. Setyowati, "Strategi Manajemen Sebagai Faktor Mitigasi Dalam Penerimaan Opini Audit Studi Empirik pada Perusahaan Manufaktur di Indonesia," MAKSIMUM, vol. 4, no. 2, 2014.

[13] S. Guritno and U. Rahardja, Theory and Application of IT Research: Metodologi Penelitian Teknologi Informasi. Penerbit Andi, 2011.

[14] N. Azizah, E. Suryana, and H. Haris, "Application of a Customer Based Data Monitoring Facility Online Accounting Software For Effectiveness Leadership at Higher Education," Aptisi Trans. Manag., vol. 1, no. 2, pp. 86-93, 2017.

[15] D. C. Cahyaningrum and I. Utami, "Apakah Tekanan Ketaatan dan Kompleksitas Tugas Berpengaruh Terhadap Keputusan Audit?," Simp. Nsional Akunt. XVIII Univ. Sumatra Utara (16-19 Sept. 2015) h, pp. 1-20, 2015.

[16] P. O. A. Sunarya and N. Lutfiani, "Analisis Sistem Sertifikasi Profesi Untuk Pengembangan Kompetensi Mahasiswa," ADI Bisnis Digit. Interdisiplin J., vol. 1, no. 1, pp. 70-77, 2020.

[17] A. Rifandi, "Analysis And Design Of Point Of Sale System In D'astore Shop," Aptisi Trans. Technopreneursh., vol. 2, no. 1, pp. 34-47, 2020.

[18] Y. Tangpinyoputtikhun and C. Thammavinyu, "1. THE IMPACT OF PROFESSIONAL KNOWLEDGE AND PERSONAL ETHICS ON AUDIT QUALITY AND SUSTAINABLE REPUTATION OF THAI-PUBLIC ACCOUNTANTS," J. Acad. Bus. Econ, vol. 10, no. 2, 2010.

[19] A. A. Arens, R. J. Elder, M. S. Beasley, and A. A. Jusuf, "Auditing and Assurance Service: An Intergrated Approach An Indonesian Adaption, Jurong." Singapore: Pearson Education South asia PTE LTD, 2012.

[20] U. Rahardja, P. A. Sunarya, Q. Aini, and S. R. Dewi, "Solusi Payment Online Berbasis Cloud Accounting Pada Manajemen Perguruan Tinggi," InfoTekJar J. Nas. Inform. dan Teknol. Jar., vol. 3, no. 2, pp. 9-15, 2019.

[21] A. I. L. Wibowo, A. D. Putra, M. S. Dewi, and D. O. Radianto, "Differences In Intrinsic Value With Stock Market Prices Using The Price Earning Ratio (Per) Approach As An Investment Decision Making Indicator (Case Study Of Manufacturing Companies In Indonesia Period 2016-2017)," Aptisi Trans. Technopreneursh., vol. 1, no. 1, pp. 82-92, 2019.

[22] A. Husain and A. Hidayatullah, "Analysis and Design Of New Student Admission Systems On MTS AL MUHTADIIN," Aptisi Trans. Technopreneursh., vol. 1, no. 2, pp. 180-191, 2019.

[23] A. Ardelean, "Auditors' ethics and their impact on public trust," Procedia-Social Behav. Sci., vol. 92, pp. 55-60, 2013.

[24] P. C. Kurniawan and F. Azmi, "The Effect of Management Morality on Accounting Fraud with Internal Control as A Moderating Variable (Study in Pemalang Regency)," Ris.

The Role Of Duty Complexity As A Moderation Of The Influence Of Auditor's Professional Knowledge And Ethics On Audit Quality (Empirical Study On Auditor At Kap Central Java)

(Widhy Setyowati) 
Akunt. dan Keuang. Indones., vol. 4, no. 2, pp. 177-185, 2019.

[25] Q. Aini, Z. Zaharuddin, and Y. Yuliana, "Compilation of Criteria for Types of Data Collection in Management of Research Methods," Aptisi Trans. Manag., vol. 2, no. 2, pp. 97-103, 2018.

[26] B. Djatmiko, M. Galinium, and N. Lutfiani, "The Role of a Variety of Research Studies on Problem Management," Aptisi Trans. Manag., vol. 2, no. 1, pp. 9-19, 2018.

[27] Arifudin, "The effect of performance incentive on audit judgement by using the effort as the intervening variable and the task complexcity as the moderating variable," Int. J. Appl. Bus. Econ. Res., vol. 12, no. 4, pp. 1305-1314, 2014.

[28] S. H. Chan, Q. Song, and L. J. Yao, "The moderating roles of subjective (perceived) and objective task complexity in system use and performance," Comput. Human Behav., vol. 51, pp. 393-402, 2015.

[29] A. S. Sudaryono and U. Rahardja, "Statistik Deskriptif Langkah Mudah Analisi Data," Yogyakarta Andi, 2010.

[30] P. A. Sunarya, M. N. M. Nawi, and S. Rahayu, "Analyze and Record a series of Purchase Transactions on Companies using Online Accounting Software," Aptisi Trans. Manag., vol. 1, no. 1, pp. 38-43, 2017.

[31] A. Mansouri, R. Pirayesh, and M. Salehi, "Audit competence and audit quality: Case in emerging economy," Int. J. Bus. Manag., vol. 4, no. 2, pp. 17-25, 2009.

[32] M. A. Al Momani and M. I. Obeidat, "The effect of auditors' ethics on their detection of creative accounting practices: A field study," Int. J. Bus. Manag., vol. 8, no. 13, p. 118, 2013.

[33] S. Sudaryono, L. Sunarya, and G. Maulani, "Facility for Customizing Transaction Forms on Master Data Using an Online Accounting System Web For Work Efficiency Company," Aptisi Trans. Manag., vol. 1, no. 1, pp. 17-23, 2017. 